\title{
CHANGES IN THE MANAGEMENT OF MUNICIPAL WASTE IN POLAND - TOWARDS THE CIRCULAR ECONOMY
}

\author{
Barbara GOLĘBIEWSKA, Faculty of Economics, Warsaw University of Life Sciences, ul. Nowoursynowska, 02-787 Warsaw, \\ Poland,166, Poland, barbara_golebiewska@sggw.pl
}

\begin{abstract}
Increasing demand for consumer goods causes more and more waste. In line with the principle of sustainable development, waste policy should aim at ensuring that waste produced has the least impact on the natural environment. One solution is to use a circular economy. According to this concept waste production should be minimized as much as possible. Therefore, action should be taken to enable all raw materials to "stay" in economy for as long as possible. Main goal of the article is defined as an assess of the changes in the generation and management of municipal waste before and after the amendment of the Clean House Act. As the research tasks were adopted to present changes in waste management legal regulations: • to indicate waste generation level in Poland, $\bullet$ the origin of the waste, $\bullet$ to analyses and evaluate changes in the field of waste recovery, recycling and reuse.

In this context there is an important question, how could we decrease production and consumption in order to generate lower quantity of waste or recycle them appropriately and use again. After the entry into force of the law on the maintenance of cleanliness and order in municipalities, there was a decrease in a production of mixed waste. Between 2012-2016 there was an increase in the amount of municipal waste picked up selectively. The amount of mixed waste recycled in 2016 has increased fourfold in comparison to 2012, and the amount of waste recycled has increased by 42 times.
\end{abstract}

Keywords: landfilling, municipal waste, recycling

\section{INTRODUCTION}

The development of civilization and the growing demand for consumer goods have caused many environmental problems unknown so far. One of them is the emergence (production by human) of many waste. It is pointed out that the cause of formation of excessive amounts of waste is irrational resource management. In Poland, there has been an increase in interest in waste management in recent years. Many legal acts and educational programs related to the proper handling of litter have been developed. According to the Act of 14 December 2012 on waste, it is defined as any substance or object which the holder discards, intends to discard or is obliged to discard (Waste ... 2012).

Kalinowska (2017) states that waste does not accumulate in nature, everything goes to the circulation of matter. However it is quite different in the economy, which generates a huge amount of waste unused further by human. In line with the principle of sustainable development, waste policies should aim to manage them in such a way as to minimize the impact on the natural environment. In addition, waste is not only associated with harmful environmental impact, but they are also economic losses. Therefore, proper management will benefit both the economy and nature. Such a solution may be the pursuit of a circular economy. According to this concept, waste production should be minimized as much as possible and waste produced should be recycled as raw materials for recycling. It would therefore be advisable to take steps that would allow all raw materials to "remain" in the economic circulation for as long as possible. These actions will help to "close the circulation" of the product life cycle by increasing recycling and reuse, which can benefit both the environment and the economy. The EU's circular economy should be aimed at achieving high resource efficiency and elimination of waste and emissions.

There are many sources of waste in the economy, including industrial, mining, construction and demolition waste, old electronic equipment, used cars, plastic bags, sanitary waste and many other unnecessary things that we throw away. The increase in the amount of waste produced is associated with demographic changes, which results in an increase in the number of households, but also in the pattern of consumption and the increasing use of technology and new products.

The transition to a circular economy provides tremendous opportunities for Europe and its citizens. One of these activities is the collection of energy from waste (eg. biogas production). As indicated by Lenerts (2013, pp. 210), landfill waste in the EU accounted for $27 \%$ of total biogas production, while $63 \%$ of biogas production comes from biological waste. Streimikiene and Mikalauskiene (2013, pp. 373) report that about 87.4 million cubic meters of biogas can be generated from biodegradable waste from the industrial and residential sectors. Kaczmarek (states that the waste management sector will develop dynamically. This concerns the development of companies engaged in recycling, waste

Copyright (C) 2017 The Authors. Published by Aleksandras Stulginskis University. This is an open-access article distributed under the terms of the Creative Commons Attribution License (CC-BY 4.0), which permits unrestricted use, distribution, and reproduction in any medium, provided the original author and source are credited. 
disposal, waste management and composting. Both the increase in the world population and the increase in consumption lead to an increase in waste. It is estimated that the UK will have to invest $£$ 9bn in the facilities for recovery of recyclables as well as waste incineration and refinement to achieve the government's target of $20 \%$ of raw materials recovered by 2020 (Kaczmarek, 2017).

Hence, the paper focuses on the analysis and evaluation of changes in the production and management of one of the components of all waste, i.e. municipal waste. Municipal waste is one of the most complex waste streams and the way in which it is managed basically reflects the quality of the entire waste management system in a given country. Challenges related to the management of municipal waste result from the highly complex and mixed composition of these wastes, the immediate vicinity of generated waste towards citizens and their very prominent visibility into the public. Countries that have developed effective municipal waste management systems typically achieve better overall waste management results in general (COM 2015).

The main objective of the study was defined as the assessment of changes in the production and management of municipal waste before and after the change in the Act on maintenance of cleanliness and order in the communes in Poland. The research tasks were:

- $\quad$ presentation of changes in the legal regulations concerning waste management,

- indication of the level of waste generation in Poland,

- identification of sources of waste origin,

- $\quad$ analysis and assessment of changes in waste recovery and disposal and reuse.

\section{METHODOLOGY OF RESEARCH}

Municipal waste is household waste, as well as waste not containing hazardous waste coming from other waste generators, which, by their nature or composition, are similar to those produced in households. Data on municipal waste refer to the amount of municipal solid waste collected, which is presented in weight units (tons). Also included are data on the types of selected solid municipal waste, collected household waste, the amount of waste disposed of in composting plants and waste incineration plants or deposited in landfills.

The source of information for the analysis was the data, among others, from the Central Statistical Office (GUS). The registers of regulatory requirements for environmental protection were helpful when using regulatory information. In addition, the data of the Central Environmental Inspectorate preparing the Environmental Status Reports (data recorded every 4 years) were included, as well as detailed information from the Local Data Bank (BDL). The work was done using the desk research method, using comparative analyses in vertical system (analysis in years). Information on waste in the years 2002-2012 was provided in accordance with the GUS data prepared on the basis of the Waste Act of 27 April 2001 (Journal of Laws 2010, No. 185 pos. 1243), whereas the data for 2013-2015 according to the Waste Act of 14 December 2012 (Journal of Laws 2013, pos. 21 as amended). In addition, the paper uses the literature on the subject and the legal acts. The obtained results are presented by means of descriptive methods, tabular and graphic compilations.

\section{RESOLUTE AND DISCUSSION}

The environment is a source of natural resources that allow production, consumption and contribute to the quality of life and human well-being. The way and rate of consumption of natural resources can weaken the capacity of ecosystems to provide us with what is necessary in the future (GIOS ... 2017). Significant quantities of potential recyclables that are present in the total waste are lost in the EU. In 2013 a total of 2.5 billion tons of waste was produced in the EU, of which more than half (1.6 billion tons) were not reused or recycled. According to estimates, another 600 million tons of waste was recyclable or reusable. For example, only $43 \%$ of municipal waste produced in the Union was recycled, while the remainder was stored $(31 \%)$ or burned $(26 \%)$. The Union thus loses a great chance to increase resource efficiency and create a circular economy (COM 2015). Of course, the differences between the countries are very large. There are countries where a small percentage of waste is stored, but there are also such one where even more than $90 \%$ of waste is deposited at landfills (Kiełsznia, 2017, Linert, 2013).

Converting waste into resources is an essential element for more efficient resource management and closing the circulation in the economy. Greater savings and increased efficiency of raw materials recovery can be achieved through better segregation of waste (Elen ... 2012). The reuse of products and materials allows saving considerable amounts of primary raw materials. For example, UK studies have estimated that $70 \%$ of primary resources can be saved when processing the existing products (Lavery, et.al., 2013).

An efficient circular economy could reduce the amount of raw materials used, but also by-products, in the form of waste and emissions. On January 1, 2012, the amendment to the Act of 13 September 1996 on the maintenance of cleanliness and order in communes and certain other acts entered into force. The most important tasks were:

- taking responsibility for municipal waste by communes,

- introduction of fees for waste management,

- building new waste treatment plants;

- Selection of entrepreneurs receiving municipal waste by the communes by tender (Act ... 2013).

Considering environmental protection, many other laws and regulations have also been adopted. These include: Act of 7 April 2017 amending the Environmental Protection Act, Act of 7 November 2017 amending the Act on packaging and packaging waste management and some other acts (Journal of Laws 2017 pos. 2056; Act of 27 October 2017 
amending the Environmental Protection Act and some other acts (Journal of Laws 2017 pos. 1999); Ordinance of the Minister of the Environment of 21 July 2017 on minimum annual levels of collection of used electrical and electronic equipment (Journal of. Laws 2017 pos. 1499).

The measures have been taken in Poland to gradually shift from a waste storage system to a system that supports the processing and recovery of raw materials and the energy use of waste. The proper management of waste is to prevent and reduce the negative impact of waste generation and management. As indicated in the Energy Security and Environment Strategy for 2020 (2014), the most important action in this regard is to ensure the functioning of a system of selective collection / receipt of municipal waste and to cover with it $100 \%$ of the population. Figure 1 shows the changes in the collection of household waste in Poland in the years 2001-2016.

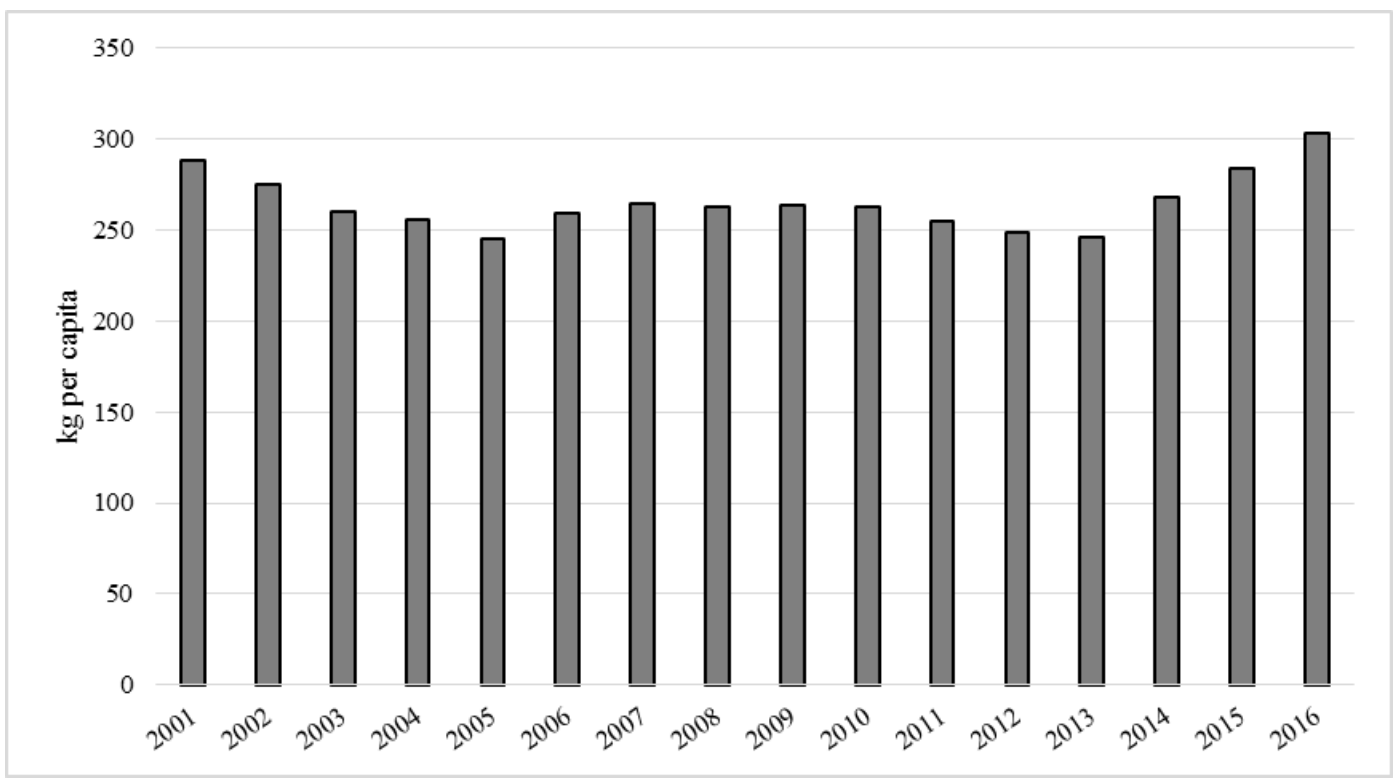

Figure 1. Municipal waste collected from households in Poland per capita in 2001-2016 Source: Environment 2006-2016. https://bdl.stat.gov.pl/BDL/dane/ (accessed on 2017/11/10)

In the years 2001-2005 there was a decrease in the amount of municipal waste collected, which was not related to the decrease of their production, but rather to the creation of wild dumps and the lack of possibility to receive them. After Poland's accession to the EU, the situation improved slightly, but by the time of the Waste Act entry into force in 2012 there was a decrease in the amount of waste collected. It can be observed that since 2013 this situation has definitely improved as it has resulted in a significant increase in collected waste in the following years. From 2012, it can also be noted that there has been an increase in the amount of municipal waste collected selectively (Fig. 2). The largest increase in the amount of waste collected separately was recorded in 2014 compared to 2013 - by as much as $60 \% .2014$ was the first full year in which the amendment to the Act on Maintaining Cleanliness and Order in Communes was obligatory. In 2015 compared to 2014, the increase in selectively collected waste amounted to $23 \%$, and in 2016 compared to 2015 it reached $17 \%$ (GUS, 2017).

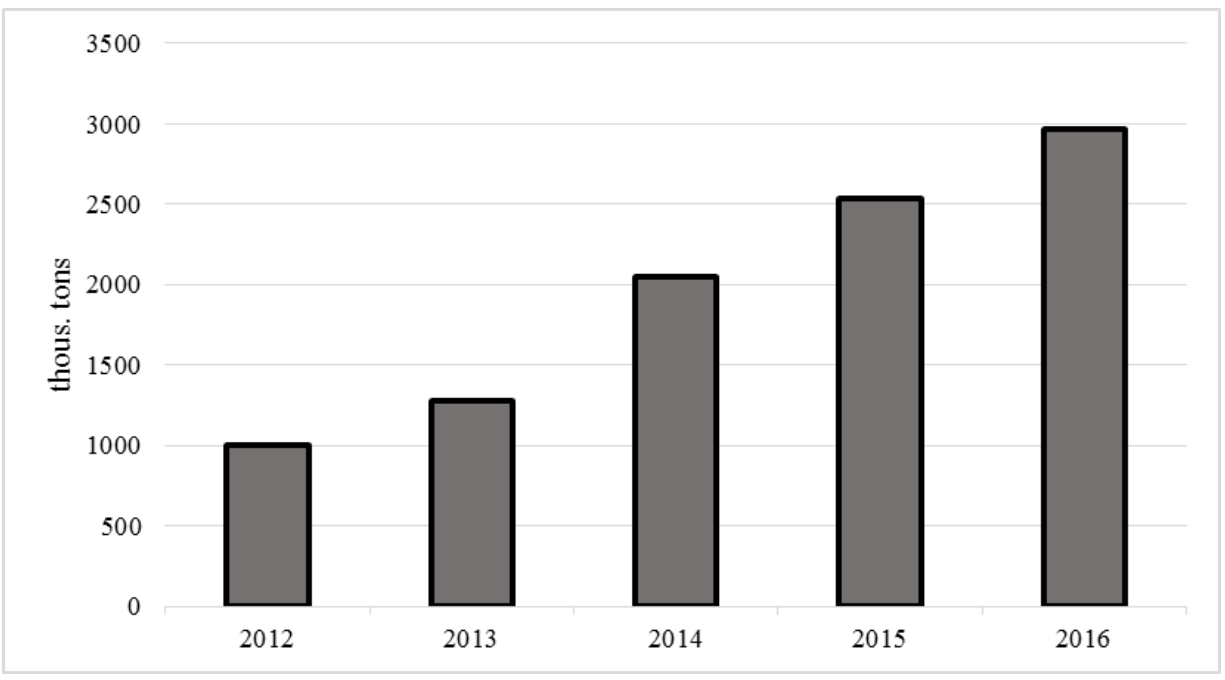

Figure 2. Waste collected selectively in Poland in the years 2012-2016 (GUS, 2017) 
The highest level of waste generated in the EU countries was achieved by Germany, France and the United Kingdom (Eurostat, 2017). A positive phenomena of the decrease in the amount of municipal waste produced per capita occurred in Poland (as in the case of 15 other countries) in comparison with other EU countries (Fig. 3).

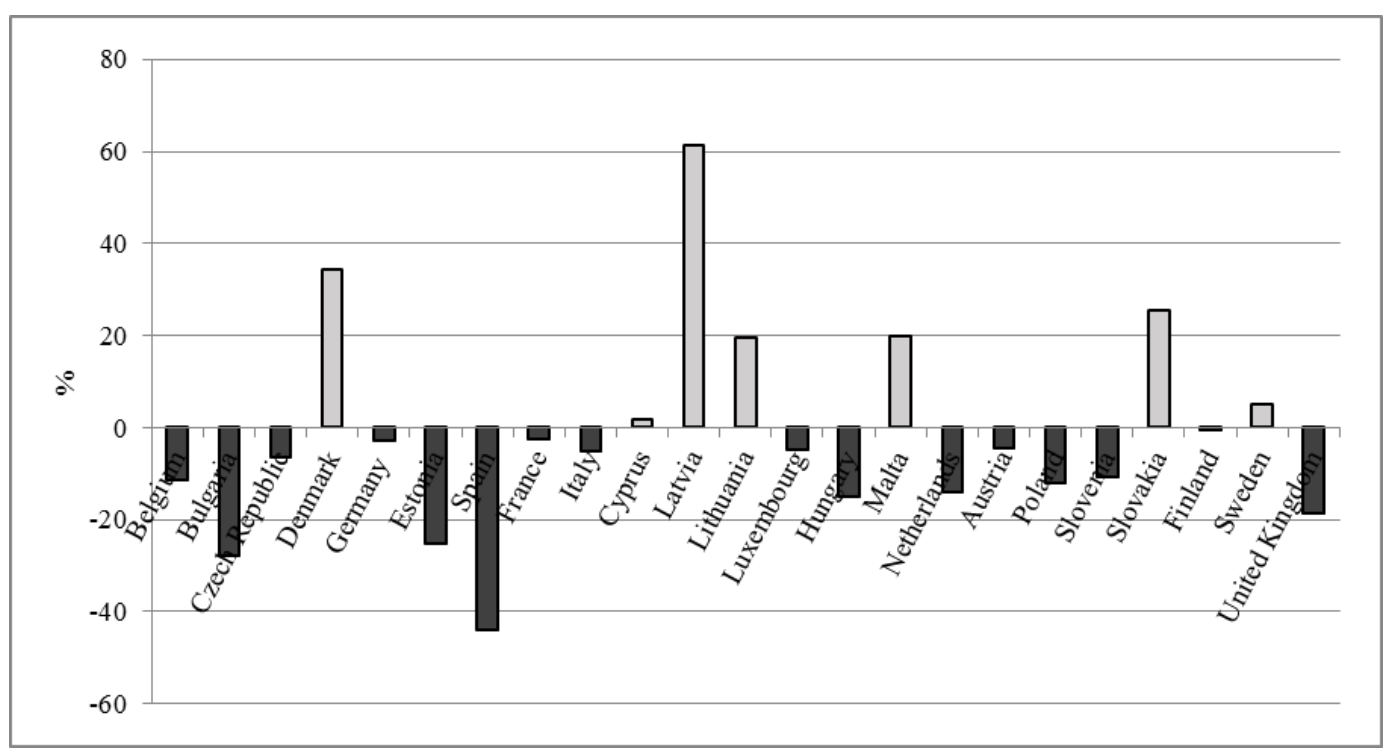

Figure 3. Changes in municipal waste production in the selected countries UE (between 2000 and 2015) (Gołębiewska, 2017)

The municipal waste management, according to the Act, takes place considering the hierarchy of waste handling methods. Mixed wastes are subjected to recycling, thermal transformation, other processing (biological treatment) and storage. Recycling is a recovery that involves the reprocessing of substances or materials contained in waste in the production process to obtain a substance or material intended for primary or secondary use. By 2016, the amount of mixed waste recycled has increased fourfold in comparison to 2012, and the amount of waste thermally transformed has increased more than thirtyfold. Another important aspect is the decrease in the amount of waste transferred to landfills (more than double). This points to positive phenomena leading to the proper management of waste.

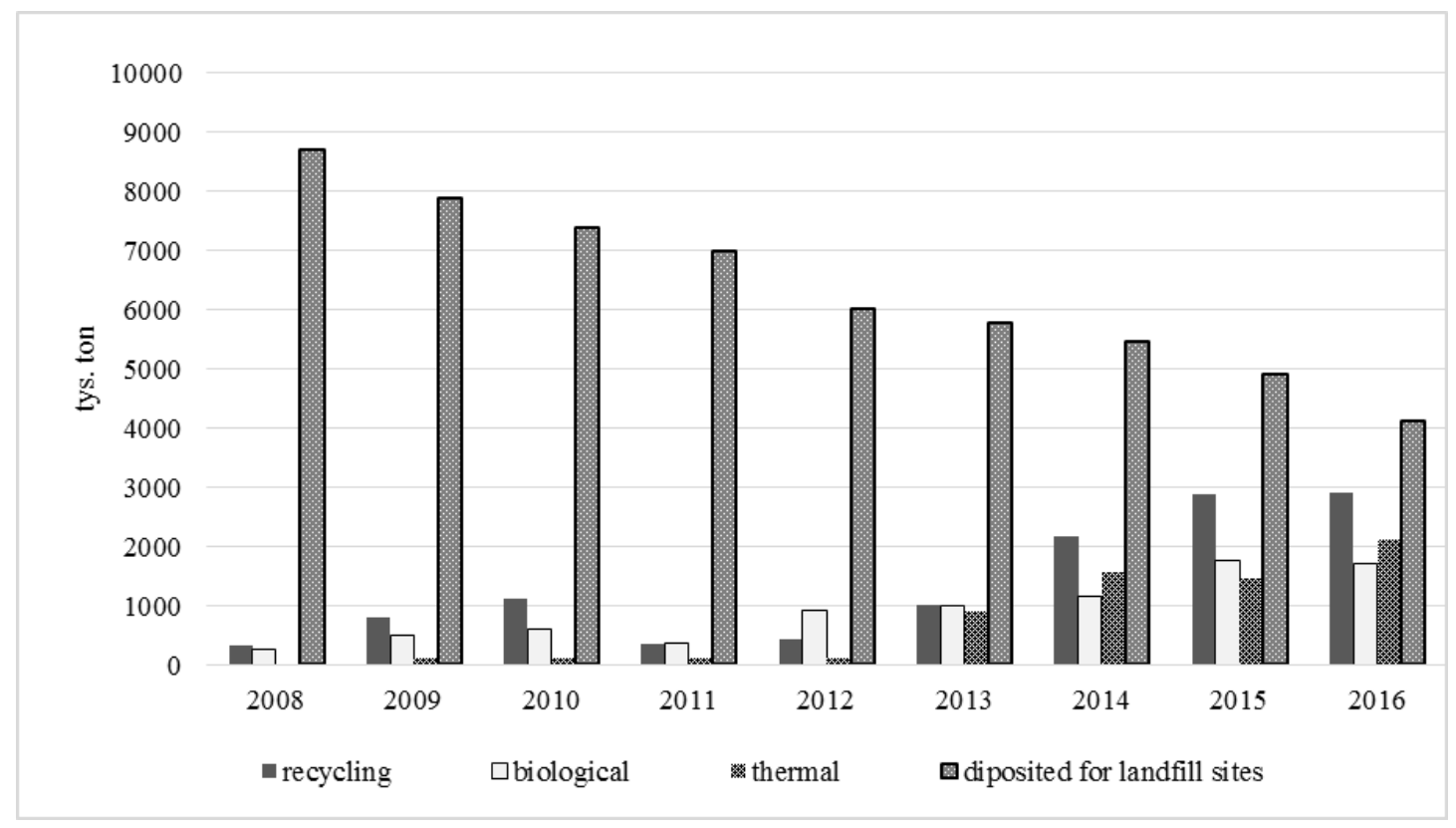

Figure 4. Management of mixed waste in Poland

Source: GUS 2010, 2017

The large increase in waste streams directed to the thermal transformation was caused by launching new municipal waste incinerators in 2015-2016. In 2013 the Regulation of the Minister of Economy of 8 January 2013 on the criteria and procedures for the acceptance of waste for storage ${ }^{1}$ was published in Poland, which also affected the increase of waste

\footnotetext{
${ }^{1}$ Landfill site is a building facility intended for landfill. There are three types of landfills: a hazardous waste landfill, inert waste landfill and a landfill for waste other than hazardous and inert waste. The stored waste is to be understood as waste disposed of at landfills (dumps, landfills, sludge ponds), plant owned or foreign (Environment 2016).
} 
directed to thermal transformation. As of January 1, 2016, there is a ban on the storage of mechanically processed waste and municipal waste for which the combustion heat is above $6 \mathrm{MJ} / \mathrm{kg}$ (GUS 2016). This is important to reduce the number of illegal local landfills, by ensuring the proper functioning of landfills properly kept (eliminating inappropriate landfill practices).

\section{CONCLUSION}

In recent years, positive effects on waste management have been observed in Poland. Measures have been taken to move away from the waste storage system to a system that seeks to process and recover raw materials from waste. Waste prevention is the most effective way to improve resource efficiency while reducing the negative impact of waste on the environment. After the entry into force of the Act on maintenance of cleanliness and order in communes, the quantity of mixed waste received has increased. In the years 2012-2016 there was also an increase in the amount of municipal waste collected selectively in Poland. This is a positive phenomenon, because too little proportion of the waste collected selectively, translates into too little progress in the processes of their recycling. A significant share of mixed municipal waste in the collected volume leads to too much quantity of municipal waste being landfilled.

The negative phenomena occurring in waste management are the consequence of insufficient education in waste management and circular economy. This is primarily due to insufficient knowledge in the field of waste reduction or their selective collection. Despite the increase in the share of recycled waste in Poland, its level remains still insufficient. There is still a large share of landfill waste, including a large number of illegal dumping sites (at the end of 2014 there were 2371 illegal dumping sites in Poland, although it was $15 \%$ less than in 2013) (Błachowicz, 2017).

The amount of municipal waste produced should be influenced by a change in the EU and national policies implemented by increasing the emphasis on the development of "circular economy". It provides an opportunity to transform the economy into a more sustainable and competitive one. Another important issue in this context is what each of us can do to produce less waste or to help recover them appropriately and reuse.

\section{REFERENCES}

1. Błachowicz K. 2017: PSZOK to wazny element systemu (PSZOK is an important element of the system). Przeglad Komunalny no 6. Available at http://master.tychy.pl/biblioteka/wp-content/uploads/2017/10/Przegl\%C4\%85d-Komunalny-nr-6-2017-3.pdf [In Polish]

2. COM 2015. Dyrektywa Parlamentu Europejskiego i Rady zmieniajaca dyrektywe 2008/98/WE w sprawie odpadow. European Commission. 595 final. Available at http://eur-lex.europa.eu/resource.html?uri=cellar:c2b5929d-999e-11e5-b3b701aa75ed71a1.0011.02/DOC (accessed on 2017/11/12) [In Polish]

3. Ellen Macarthur Foundation. 2012. Towards a Circular Economy: From linear to circular Accelerating a proven concept, no 2. Available at https://www.ellenmacarthurfoundation.org/assets/downloads/publications/Ellen-MacArthur-Foundation-Towardsthe-Circular-Economy-vol.1.pdf (accessed on 2017/10/12)

4. Environment (2006, 2010, 2016). Statistical Information and Elaborations, Central Statistical Office, Warsaw.

5. Eurostat 2017. Available at http://ec.europa.eu/eurostat/statistics-explained/index.php/Waste_statistics. (accessed on 5/10/2017).

6. GIOS. 2015. Program Panstwowego Monitoringu Srodowiska na lata 2016-2020. Glowny Inspektor Ochrony Srodowiska (National Monitoring Program for the Environment 2016-2020. Chief Inspector of Environmental Protection. Warsaw, 2015.

7. GIOS. 2017. Stan srodowiska w Polsce. Sygnaly 2016 (Environmental condition in Poland. Signals 2016). Warszawa.

8. Gołębiewska, B. 2017. Changes in Waste Management in the EU. Proceedings of the International Scientific Conference. Jelgava. Economic Science and Rural Development. No 45, pp. 87-94.

9. GUS (Central Statistical Office of Poland). 2010. 2012. 2014. Statistical Yearbook of Agriculture, Warsaw. [In Polish]

10. GUS (Central Statistical Office of Poland) 2017. A change of the system of municipal waste management in Poland in the years 2012-2016. Inspection study. Available at http://eur-lex.europa.eu/resource.html?uri=cellar:c2b5929d-999e-11e5-b3b701aa75ed71a1.0011.02/DOC_1\&format=PDF (accessed on 2017/11/08) [In Polish]

11. Journal of Laws 2010, No. 185 pos. 1243.

12. Journal of Laws. 2013. Waste Act of 14 December 2012, Art. 3, item. 21, as amended.

13. Kaczmarek, T., 2017. Dlaczego warto inwestowac w ekologie? (Why invest in ecology?), Ekologia.pl. Environmental protection Doradca Inwestycyjny Domu Maklerskiego BZ WBK. Available at http://www.ekologia.pl/srodowisko/ochronasrodowiska/dlaczego-warto-inwestowac-w-ekologie,4832.html (accessed on 2017/11/12) [In Polish]

14. Kalinowska, A. 2017. Gospodarka o obiegu zamknietym - fanaberia czy koniecznosc? (The economy of closed cycle - fanaberia or necessity) Kongres Obywatelski. Idee dla Polski (Civic Congress. Ideas for Poland). Available at https://www.kongresobywatelski.pl/wp-content/uploads/2017/06/anna_kalinowska-gospodarka_o_obiegu_zamknietymfanaberia_czy_koniecznosc.pdf (accessed on 2017/10/27) [In Polish]

15. Kiełsznia, M. 2011. Procedury ocen oddzialywania na srodowisko dla projektow z zakresu termicznego przeksztalcania odpadow (Procedures for environmental impact assessments for thermal waste conversion projects). Generalna Dyrekcja Ochrony Srodowiska (General Directorate for Environmental Protection). Available at https://www.mos.gov.pl/g2/big/2011_05/f61d5b0e851cc44e6660140fffc30b8a.pdf (accessed on 2017/10/27) [In Polish] 
16. Lavery, G., Pennell, N., Brown, S. Evans, S. 2013. Next Manufacturing Revolution, The Next Manufacturing Revolution: NonLabour Resource Productivity and its Potential for UK Manufacturing. Available at http://www.nextmanufacturingrevolution.org/wp-content/uploads/2013/09/Next-Manufacturing-Revolution-full-report.pdf (accessed on 2017/10/30)

17. Lenerts, A. 2013. Sustainable Use of Bio-resources of Agricultural Origin: the Basis of Bioeconomy in Latvia, Proceedings of the International Scientific Conference. Proceedings of the International Scientific Conference "Rural Development 2013", Vol. 6, Book 1, pp. 209-213.

18. Linert, S. 2013. Europa nie chce skladowisk odpadow!!! Jakie jest stanowisko i rola Polski??? (Europe does not want waste dumping grounds!!! What is the position and role of Poland???). Instytut Inicjatyw Edukacyjnych i Europejskie Centrum Ksztalcenia Praktycznego we Wloclawku - Polska (Institute for Educational Initiatives and European Center for Practical Education in Wloclawek - Poland).

19. Local Data Bank 2015, 2016. Mass of generated municipal waste by one resident. Available at https://bdl.stat.gov.pl/BDL/dane/ (accessed on 2017/11/10). [In Polish]

20. Makarevičienė, V., Kalenska, S., Skorupskaite, V., Yunik, A., Gumbytė, M. 2013. The use of Oilseed Meal for the Production of Biogas. Proceedings of the International Scientific Conference, "Rural Development 2013”. Vol. 3, Book 1, pp. 75-78.

21. Streimikiene, D., Mikalauskiene, A. 2013. Willingness of Lithuanian Households to Pay for Electricity Produced from Renewables. Proceedings of the International Scientific Conference, "Rural Development 2013". Vol. 6, Book 1, pp. 372-376 . 